Marquette University

e-Publications@Marquette

Library Faculty Research and Publications

Library (Raynor Memorial Libraries)

$1-1-1990$

\title{
An Assessment of Education and Training Needs for Bibliographic Instruction Librarians
}

Scott Mandernack

Marquette University, scott.mandernack@marquette.edu

Accepted version. Journal of Education for Library and Information Science, Vol. 30, No. 3 (Winter 1990): 193-205. Permalink. (C) 1990 Association for Library and Information Science Education. Used with permission. 


\title{
An Assessment of Education and Training Needs for Bibliographic Instruction Librarians
}

\author{
Scott B. Mandernack
}

\begin{abstract}
A study was conducted in 1986 by the Education and Library Use Committee of the Wisconsin Association of Academic Librarians to determine the educational backgrounds and characteristics of bibliographic instruction (BI) librarians in Wisconsin. The results of the survey indicated that the education for $\mathrm{BI}$ has been insufficient and that there is a very real need for additional and/or supplemental education in this area. The methods most preferred for educational enhancement are self-study and workshops. A recommendation was made for one approach to resolving the dilemma: offering a series of courses, in the form of one- to three-day seminars, through the University of Wisconsin Certificate of Professional Development Program. This organized program of study now offers a bibliographic instruction track, consisting of four core courses, which is to be supplemented with additional electives. Until such time as library instruction is standard fare and fully integrated into our library school offerings, it is the hope that this approach may serve as a model for one method of accommodating the educational needs of instruction librarians.
\end{abstract}


The importance of library instruction in academic libraries is well established, and its theory and practice continue to develop. It is expected of nearly every public service librarian and from a growing number of librarians in other service areas as well. Yet even with the well-established place of library instruction within the profession, the education and training of instruction librarians is sorely lacking. There seems to be no consensus as to whether formalized education devoted to this area of librarianship is indeed even warranted.

The problem has been chronicled repeatedly in the literature for over ten years. ${ }^{1}$ Library school offerings that are relevant to $\mathrm{BI}$ are still quite limited. Very often $\mathrm{BI}$ is treated only as a component of another course, and those schools that do offer full courses are relatively few in number. In 1984 the great majority of library schools (91\%) had integrated bibliographic instruction into existing courses, with 32\% offering a separate course. Nine percent had no BI components in their curriculum. In 1986 there was a significantly greater proportion of library schools offering no BI in their curriculum (33\%) as well as a decline in those schools offering a separate course $(26 \%){ }^{2}$

Reasons cited for the reluctance of library schools to incorporate courses in bibliographic instruction are numerous, including:

- a hesitancy to cross over into the "territory" of education departments;

- too broad a scope to be covered in a single course (adequate coverage of the subject would require additional courses, thereby preempting other, "necessary" courses);

- disagreement on the material to be covered (i.e., theory or practice);

- inability of existing library school faculty to teach such a course; and

- lack of demand from library school students, due, in part at least, to an unfamiliarity with career expectations. $^{3}$

Yet in spite of this lack of formal training, libraries, as employers, insist on "knowledge of" or "experience in" bibliographic instruction when hiring reference/public service positions. In a study of the amount and importance of various professional knowledge bases among academic librarians, library instruction ranked 19th of 56 and was measured in importance at 2.55 on a 5-point scale ( 1 = essential, $5=$ of no importance). ${ }^{4}$ The new graduate is faced with a very real dilemma, one apparent upon first glance at a few position announcements.

So how do we approach this problem? Do we first encourage employers to demand specified prerequisites of instruction librarians, thereby demonstrating to the library schools the need for such training? Or, conversely, do we first approach the library schools to establish appropriate courses for training instruction librarians so that employers have some basis on which to require previous knowledge?

Supplementary educational opportunities for instruction librarians are indeed available, but they tend not to be offered in any systematic fashion. This often results in duplication and/or omission of key points or concepts, not to mention uneven emphasis on the theories, philosophies, and practice of bibliographic instruction. Such uneven coverage may be compensated for over time, but often only through years spent attending conferences, workshops and seminars, reading independently, talking and meeting with peers, etc. Given this situation, an alternative and/or supplemental means of preparing BI librarians would seem to be appropriate. 


\section{Methodology}

A survey was conducted in 1986 by the Education and Library Use Committee of the Wisconsin Association of Academic Librarians (W\AL). The purpose of the study was to determine the general and educational background characteristics of bibliographic instruction librarians in Wisconsin, to identify the extent of their $\mathrm{BI}$ activities, and to gather information that would provide a basis for the development of future offerings in the education of instruction librarians. Questionnaires, adapted from that used by Smith, ${ }^{5}$ were mailed to each of the 400 members of WAAL. Members of this group represent college, university, vocational/ technical, junior college, and special libraries. Only those librarians with library instruction experience were asked to complete the survey; those without the relevant experience were asked to return the form unanswered.

The survey tool (see appendix A) consisted of thirty questions designed to provide data to meet the following objectives:

1. To determine the methods and the extent of bibliographic instruction currently being practiced among instruction librarians;

2. To determine if librarians engaged in bibliographic instruction received relevant education and training, particularly in learning theory, teaching methodology, and/or instructional development; 3. To determine how the education, training, and experience related to bibliographic instruction were gained;

4. To identify education and training needs of bibliographic instruction librarians and appropriate methods of achieving them; and

5. To gather limited demographic information about the population.

\section{Results}

Of the 400 questionnaires mailed, 180 responses were received, representing a $45 \%$ return rate. Of these responses, $68(38 \%)$ were returned blank, indicating that $112(62 \%)$ of the respondents had been or were presently involved in library instruction activities.

Two-thirds of the instruction librarians in Wisconsin are over forty years old; only $5 \%$ are under thirty. Seventy percent received their library science degrees over ten years ago and $13 \%$ are recent graduates, having earned their degrees in the past four years. They are practicing instruction in all types of institutions (including junior college, vocational/ technical college, and special libraries), though by far the majority (86\%) are in college and university libraries. (See table 1 ). 
Table 1. Demographic Characteristics $(N=112)$

\begin{tabular}{|c|c|c|}
\hline Characteristic & Frequency & Percent \\
\hline \multicolumn{3}{|l|}{ Age } \\
\hline $20-29$ & 6 & 5 \\
\hline $30-39$ & 36 & 32 \\
\hline $40-49$ & 40 & 36 \\
\hline 50 or older & 29 & 26 \\
\hline No response & 1 & -- \\
\hline \multicolumn{3}{|l|}{ Years since M.L.S. degree earned } \\
\hline $0-4$ & 14 & 13 \\
\hline $5-9$ & 19 & 17 \\
\hline $10-14$ & 39 & 35 \\
\hline $15-19$ & 23 & 21 \\
\hline 20 or more & 15 & 14 \\
\hline No response & 2 & -- \\
\hline \multicolumn{3}{|c|}{ Years involved in instruction activities } \\
\hline $0-2$ & 14 & 13 \\
\hline $3-5$ & 26 & 24 \\
\hline $6-8$ & 24 & 22 \\
\hline $9-11$ & 13 & 12 \\
\hline 12 or more & 32 & 29 \\
\hline No response & 3 & -- \\
\hline \multicolumn{3}{|l|}{ Library instruction assignment* } \\
\hline Full-time & 1 & 1 \\
\hline Half-time & 3 & 3 \\
\hline Less than half-time & 106 & 96 \\
\hline No response & 2 & -- \\
\hline \multicolumn{3}{|l|}{ Type of library } \\
\hline Junior college & 3 & 3 \\
\hline Vocational/technical & 6 & 5 \\
\hline College & 26 & 23 \\
\hline University & 70 & 63 \\
\hline Special & 3 & 3 \\
\hline Other & 4 & 4 \\
\hline
\end{tabular}

Sixty-three percent of these librarians have been engaged in bibliographic instruction activities for six or more years, leaving $37 \%$ who have been involved less than six years; $13 \%$ have been practicing library instruction less than three years. Nearly all are full-time employees practicing BI less than half-time. The job-related duties of instruction librarians fall into all service areas, though collectively they have principal assignments in reference (representing $30 \%$ of their duties), administration (24\%), and instruction (12\%). Interestingly, only $57 \%$ of the respondents indicated a proportion of time specifically devoted to instruction activities. (However, this may be partially explained by the typically close association with reference, making the distinction between the two difficult to determine.) This group devoted an average of $34 \%$ of their time to instruction activities and $43 \%$ to administrative duties. In addition to the proportion of time spent on instruction activities, the extent of the various types and modes of instruction was determined. As expected, course-related instruction is the most prevalent type of instruction. It is practiced by $70 \%$ of the respondents and accounts for $49 \%$ of the total population's instruction activities. Instruction that is unrelated to a specific course (e.g., orientations, handouts) is 
used by $68 \%$ of the respondents, accounting for $25 \%$ of the activities. All the various modes of instruction are evident in the activities of these librarians. The modes of instruction used most extensively are (1) the production of handouts and guides and (2) the single lecture; each of these was reported by $87 \%$ of the population. These formats were followed, in order of use, by the presentation of guided tours (82\%), audiovisual presentations (38\%), a series of lectures $(26 \%)$, a self-paced guide or workbook (23\%), credit courses (12\%), and computer-assisted instruction (8\%). (See table 2).

Table 2. Extent of Library Instruction Activities ( $=112$ )

\begin{tabular}{|c|c|c|c|c|}
\hline \multicolumn{5}{|c|}{ Proportions of job-related duties } \\
\hline & & Frequency & $\begin{array}{c}\% \text { of activities } \\
\text { among respondents }\end{array}$ & $\begin{array}{c}\% \text { of activities of } \\
\text { entire sample } \\
\text { population }\end{array}$ \\
\hline \multicolumn{5}{|l|}{ Duty } \\
\hline & Acquisitions & 43 & 18 & 7 \\
\hline & Administration & 58 & 43 & 24 \\
\hline & Automation/Systems & 26 & 19 & 5 \\
\hline & Cataloging & 28 & 29 & 8 \\
\hline & Circulation & 21 & 14 & 3 \\
\hline & Instruction & 60 & 20 & 12 \\
\hline & Reference & 92 & 34 & 30 \\
\hline & Other & 41 & 26 & 10 \\
\hline & No response & 6 & -- & -- \\
\hline \multicolumn{5}{|c|}{ Type of instruction } \\
\hline \multicolumn{5}{|l|}{ Type } \\
\hline & Unrelated to specific course & 76 & 35 & 25 \\
\hline & Course-related & 88 & 59 & 49 \\
\hline & Course-integrated & 45 & 39 & 17 \\
\hline & Credit course & 12 & 36 & 4 \\
\hline & No response & 5 & -- & -- \\
\hline \multicolumn{5}{|c|}{ Modes of instruction used } \\
\hline & & & Frequency & $\%$ of respondents \\
\hline \multicolumn{5}{|c|}{ Mode } \\
\hline & Handouts/guides & & 94 & 87 \\
\hline & Guided tours & & 78 & 72 \\
\hline & Self-paced guide/workbook & & 25 & 23 \\
\hline & Computer-assisted program & & 9 & 8 \\
\hline & Audiovisual presentation & & 41 & 38 \\
\hline & Single lecture & & 94 & 87 \\
\hline & Series of lectures & & 28 & 26 \\
\hline & Credit course & & 13 & 12 \\
\hline & Other & & 10 & 9 \\
\hline & No response & & 4 & -- \\
\hline
\end{tabular}


The education and training backgrounds of these librarians, as they pertain to library instruction, are very diverse. Sixty percent indicate some knowledge of learning theory, teaching methodology, and/or instructional development. This knowledge was most often received as a component part of a formal program of study. Only sixteen individuals received it as part of their library science master's degree program, and eleven of them had had prior education in these areas in their undergraduate program. All but one of these sixteen earned their library science degrees ten or more years ago. Even with the increase of BI responsibilities among librarians in all service areas, no recent graduates have incorporated such back- ground knowledge directly with their library science program.

The most frequently reported method of preparation or training for BI was through self-study ( $83 \%$ of the respondents), followed by attendance at workshops (62\%) and conferences (60\%). Most respondents indicated that several methods were employed. Whereas the frequency of use of these methods of preparation gives some indication of their perceived value, respondents were also asked which one method they considered to have been the primary means by which they gained knowledge relevant to bibliographic instruction. The method most often cited as primary was self-study (reported by $52 \%$ of the population), whereas only $16 \%$ considered workshops to have been their primary means and only $9 \%$ conference programs. That these methods are the most used is supported by the amount of reading that these librarians engage in and by their professional involvement. Seventy-seven percent of the respondents regularly read three or more library-oriented journals, and $91 \%$ belong to two or more library-related professional organizations, with 35\% belonging to four or more. Forty-eight percent regularly read at least one education-oriented journal and $22 \%$ belong to two or more education-related professional organizations. Prior teaching experience, either elementary, secondary or college level, was reported by $54 \%$ of the respondents.

The wide variety of educational backgrounds of these librarians clearly demonstrates the fragmented nature of acquiring a knowledge base for library instruction. Compounding this fragmentation is the lack of a standard body of knowledge for the field. More than half $(52 \%)$ of the respondents felt they were not adequately prepared to undertake their responsibilities when they first became involved in bibliographic instruction. Only $38 \%$ of the respondents felt they were adequately prepared, and $10 \%$ were undecided. This situation further supports the need for a more systematic method of educating and preparing instruction librarians for the duties they will assume.

Those areas for future education or training for $\mathrm{BI}$ that were identified as being most beneficial are, in order of preference: (1) program development and management, (2) teaching methodology, (3) instructional development, and (4) learning theory. As to the format of presentation for learning these skills and concepts, the most preferred methods of preparation for librarians new to bibliographic instruction are ranked as follows: (1) workshops, (2) in-service training programs, (3) previous teaching experience, and (4) credit courses. For those librarians already practicing $\mathrm{BI}$, the most preferred methods of keeping abreast of new developments and further refining their skills are: (1) workshops, (2) in-service training programs, (3) conferences, and (4) self-study.

\section{Conclusions}

The survey indicated that a large proportion of practicing librarians received their library science education quite some time ago. With such tremendous growth in the field of library instruction, it is difficult to maintain a thorough, well-rounded awareness and knowledge of continuing developments and practices. Self-study and workshops, the methods most frequently employed both to learn about BI initially and to keep abreast of new trends, are often insufficient, depending upon chance and availability. Formal programs of study account for a very small percentage of appropriate educational 
background that relates educational theories and librarianship, and no such background was reported among recent graduates. Proficiencies for practicing library instruction may very well accumulate over time, through various methods, but there are no assurances that the necessary skills and knowledge will be obtained by all those who will be practicing library instruction. A list of proficiencies has been compiled, ${ }^{6}$ which indicates some progress toward the necessary standardization, but the means of gaining these proficiencies and of ensuring that they are being obtained by all instruction librarians are not yet in place.

As one more step toward this goal, a recommendation was forwarded to the University of WisconsinExtension, Communication Programs office to develop courses that would be offered through the Certificate of Professional Development Program (now offered through the University of WisconsinMadison, School of Library and Information Studies, Continuing Education Services). This program provides an organized continuing education curriculum structured with required and elective courses. The courses are presented in the form of one- to three-day seminars, with each course providing designated Continuing Education Units (CEUs). Upon completion of the specified series of courses and a minimum of twelve CEUs, participants receive a Certificate of Professional Development. Based on the results of the survey, a trial course, entitled "Methods and Techniques of Bibliographic Instruction," was offered in the fall of 1987. The enrollment in this course was enough to establish a full Certificate of Professional Development in Bibliographic Instruction program. This and three other courses - "Program Design and Development of Library Services," "Teaching Methods and Learning Theory," and "Research Strategies for Bibliographic Instruction" - compose the required core courses for this certificate.

As the theories, philosophies, and practice of bibliographic instruction develop, it becomes apparent that a fuller and more complete comprehension of the teaching function in librarianship is vitally important. This study has revealed a very real interest and need for a more satisfactory means of preparing librarians to teach library use. Given the widespread practice of BI and the inadequacy of our present situation, this course of action may serve as a model for one more approach to accommodate the educational needs of instruction librarians and present some progress in providing bibliographic instruction its rightful place in library education. 


\section{References}

1. Beaubien, A., George, M, and Hogan, S., "Things We Weren't Taught in Library School: Some Thoughts to Take Home," in Putting Library Instruction in Its Place: In the Library and in the Library School, ed. C. Kirkendall (Ann Arbor, Mich.: Pierian Press, 1978); Brundin, R. "Education for Instructional Librarians: Development and Overview," Journal of Education for Library and Information Science 25:177-89 (Winter 1985); Bunge, C., "Library Education for Library Instruction: How the Practitioners and the Educators Can Cooperate," in Putting Library Instruction in Its Place: In the Library and in the Library School, ed. C. Kirkendall (Ann Arbor, Mich.: Pierian Press, 1978); Hogan, S., "Training and Education of Instruction Librarians," Library Trends 29:105-26 (Summer 1980); Kirkendall, C., "Should Library Schools Teach Library Instruction?" Journal of Academic Librarianship 8:34-35 (March 1982); Larson, M., and Meltzer, E., "Education for Bibliographic Instruction," Journal of Education for Library and Information Science 28:9-16 (Summer 1987).

2. Larson and Meltzer, p. 13-14.

3. Brundin, p.180-81; Larson and Meltzer, p.11-12.

4. Powell, R., and Creth, S., "Knowledge Bases and Library Education," College \& Research Libraries 47:16-27 (January 1986).

5. Smith, B., "Education and Training Characteristics of Librarians Engaged in Bibliographic Instruction in Eighteen Colleges and Universities in Pennsylvania" (Ph.D. diss., Pennsylvania State University, 1981).

6. Association of College and Research Libraries, Bibliographic Instruction Section, Education for Bibliographic Instruction Committee, "Proficiencies for Bibliographic Instruction Librarians" (Chicago: American Library Assn., 1985). 


\section{Appendix A.}

\section{Questionnaire: Education and Training Needs of Instruction Librarians}

Note: This questionnaire is intended for librarians who have had experience in bibliographic instruction, either currently or in the past. If you have not had such experience, please do not complete the questionnaire, and return it unanswered in the enclosed envelope.

1. How many years have you been engaged in bibliographic instruction activities?

$\begin{array}{ll}0-2 \text { years } & 9-11 \text { years } \\ 3-5 \text { years } & 12 \text { or more years } \\ 6-8 \text { years } & \end{array}$

2. How much of your assigned time in the past two years was devoted to bibliographic instruction? Full-time Half-time Less than half-time

3. Are you a full-time employee? Yes No

4. What proportion of your job-related duties is devoted to each of the following assignments (should equal 100\%)?

\begin{tabular}{l}
\hline Acquisitions \\
Administration \\
Automation/Systems \\
Cataloging
\end{tabular}

\begin{tabular}{ll}
\hline & Circulation \\
& Instruction \\
& Reference \\
Other (specify) &
\end{tabular}

5. What modes of instruction are you using? Handouts/guides (use of single source, specific activity, or specific area of library) Guided tour Self-paced guide/workbook (series of activities/exercises) - print form Computer-assisted programs Audiovisual presentations Single lecture Series of lectures Credit course Other (specify)

6. What percentage of your instruction activities are: unrelated to a specific course (i.e., orientations, handouts, etc.) course-related course-integrated credit course 
7. How many years ago did you earn your master's degree in library science?

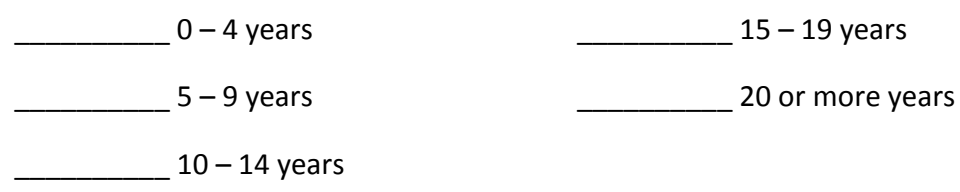

8. In your work toward your master's degree in library science, in which area of librarianship did you concentrate?

$\ldots$ Acquisitions
Administration
Automation
Cataloging

Reference
Other (specify)
No concentration

9. Have you had any education or training in learning theory, teaching methodology, or instructional development?
Yes
No
Don't know

10. If you answered "Yes" to item 9, was this knowledge gained through any of the following (check all that apply)? If you answered "No" or "Don't know" to item 9, proceed to item 11.

Undergraduate degree coursework

Library science master's degree program

Post-master's advanced study program

Master's degree program, other than library science (specify discipline)

Doctoral degree program (specify discipline)

11. Was any specific training beyond the master's degree in library science required by your library to qualify you for bibliographic instruction activities?
Yes
No
Don't know

12. In which of the following additional methods of preparation/training for bibliographic instruction have you participated?

$\begin{array}{ll}\text { Self-study } & \text { Credit courses } \\ \text { In-service training } & \text { Other } \\ \text { Workshops } & \text { None }\end{array}$

Conference programs

13. If you checked any of the selections listed in item 12, did you participate in these activities before or after you became involved in bibliographic instruction? If you checked "None" in item 12, proceed to item 15.
Before
After
Both before and after

14. Which one method (excluding formal education programs) would you say is the primary means by which you have gained knowledge and information relevant to bibliographic instruction?

Self-study

In-service training

Workshops
Conference programs

Credit courses

Other 
15. You are a member of how many library-related professional organizations?

$\begin{array}{cr}0-1 & 4-5 \\ 2-3 & 6 \text { or more }\end{array}$

16. You are a member of how many education-related professional organizations?

$\begin{array}{rr}0-1 & 4-5 \\ 2-3 & 6 \text { or more }\end{array}$

17. How many library-oriented journals do you read regularly (i.e., every issue)?

$\begin{array}{lr}0 & { }^{2} \\ 1 & 3 \text { or more }\end{array}$

18. How many education-oriented journals do you read regularly (i.e., every issue)?

$\begin{array}{rr}{ }^{0} & { }^{2} \\ & 1\end{array}$ or more

19. Did you teach at the college level prior to your involvement in bibliographic instruction?

Yes $\quad$ No

20. Did you teach at the elementary or secondary school level prior to your participation in bibliographic instruction? Yes No

21. Would you say that you were adequately prepared to undertake your responsibilities when you first became involved in bibliographic instruction?

Yes

No

Undecided

22. Do you now feel qualified to provide the type(s) of bibliographic instruction required of you at your institution?
Yes
No
Undecided

23. If you had an opportunity for additional education or training relevant to library instruction, which area(s) do you think would benefit from most? Please rank the following choices, with " 1 " being most beneficial; if none needed, simply mark the appropriate space.

Instructional development
Learning theory
Program development/management
Teaching methodology
Other (specify)
None needed


24. Which method(s) would you say offer(s) the best means of preparation for librarians new to bibliographic instruction? Please rank the following choices, with " 1 " being most preferred; if you dislike any of the choices, indicate with a " 0 ."

Self-study

In-service training

Conferences

Workshops

Credit courses

Advanced study programs (organized program of courses)

Previous teaching experience

Other (specify)

25. Which of the following methods do you see as most desirable for presenting instruction-related knowledge and information to other librarians already involved in bibliographic instruction? Please rank the following choices, with " 1 " being most desirable; if you dislike any of the choices, indicate with a " 0. "

Self-study

In-service training

Conferences

Workshops

Credit courses

Advanced study programs (organized program of courses)

Other (specify)

26. Would you say that your library administration is supportive of a bibliographic instruction program?
Yes
No
Undecided

27. Are you aware of the Certificate of Professional Development Program offered by the University of Wisconsin - Extension?

Yes No

28. If you answered "Yes" to item 27, do you think such a format is appropriate for educating and training instruction librarians? If you answered "No" to item 27, proceed to item 29.

Yes

No

Undecided

29. In what type of institution are you currently employed?

Junior college library

Vocational/technical college library

College library

University library

Special library

Other 
30. What is your age?

$\begin{array}{lr}20-29 & 40-49 \\ 30-39 & 50 \text { or older }\end{array}$

31. Comments:

This survey has been adapted from: Smith, Barbara J., "Education and Training Characteristics of Librarians Engaged in Bibliographic Instruction in Eighteen Colleges and Universities in Pennsylvania." Ph.D. dissertation, Pennsylvania State University, 1981. 